\title{
Soluble L-Selectin (sCD62L) Umbilical Cord Plasma Levels Increase with Gestational Age
}

\author{
CHRISTOPH BÜHRER, DIETGER STIBENZ, JOHANNES GRAULICH, ULRIKE GERNHOLD,
} EUGENE C. BUTCHER, JOACHIM W. DUDENHAUSEN, AND MICHAEL OBLADEN

Departments of Neonatology [C.B., D.S., J.G., U.G., M.O.] and Obstetrics [J.W.D.], Rudolf Virchow

Medical Center, Berlin Free University, D-14059 Berlin, Germany, and Department of Pathology

[E.C.B.], Stanford University Medical Center, Stanford, California 94305

\begin{abstract}
$\mathrm{L}$-Selectin $(\mathrm{CD} 62 \mathrm{~L})$ is a leukocyte surface membrane glycoprotein involved in extravasation and homotypic aggregation which is rapidly cleaved off after cellular activation. From culture supernatants and body fluids, soluble L-selectin (sCD62L) has been recovered with its functional activity retained. We devised a sensitive enzyme-linked immunoassay for quantitation of $\mathrm{SCD} 62 \mathrm{~L}$ which was used to measure $\mathrm{SCD} 62 \mathrm{~L}$ in umbilical cord plasma of 255 human newborns with a gestational age (GA) of 23-43 wk (median 38 wk). sCD62L levels ranged from $1.14-13.8 \mathrm{pmol} / \mathrm{mL}$ (median $7.2 \mathrm{pmol} / \mathrm{mL}$ ) and showed strong correlations with GA $(r=0.71, p<0.001)$, birth weight $(r=$ $0.66, p<0.001)$, and absolute neutrophil cell counts (ANC) $(r=$ $0.62, p<0.001)$ obtained from a peripheral vein within the first $6 \mathrm{~h}$ of life $(n=153)$, whereas there was a weak inverse correlation with absolute normoblast counts $(r=-0.27, p<$ $0.001)$. In multiple regression analysis, only GA and ANC retained a significant association with SCD62L levels $(p<$ 0.001). Decreased sCD62L levels were found to be associated with multiple gestation $(4.8 \pm 2.4 \mathrm{pmol} / \mathrm{mL}$ versus $7.7 \pm 2.3$
\end{abstract}

ABSTRAC
CD62L is a surface membrane glycoprotein expressed by nucleated blood and bone marrow cells (1). By initiating reversible attachment of leukocytes to endothelial cells lining the wall of postcapillary venules $(2,3), \mathrm{CD} 62 \mathrm{~L}$ is pivotal in directing neutrophils into areas of acute inflammation (4), and lymphocytes into secondary lymphoid organs (5) and sites of chronic inflammation (6). CD62L has also a role in homotypic aggregation of neutrophils (7) and lymphocytes (8) and has been implicated in the adhesion of flowing neutrophils to immobilized platelets (9). The function of CD62L present on $\mathrm{CD}^{+} 4^{+}$bone marrow hematopoietic progenitor cells $(10,11)$ is presently unknown.

The extracellular domain of CD62L is rapidly cleaved off proteolytically after leukocyte activation in vitro (12-16) and

Received September 6, 1994; accepted March 14, 1995

Correspondence: Dr. Christoph Bührer, Kinderklinik KAVH, Virchow-Klinikum, Humboldt-Universität, Heubnerweg 6, D-14059 Berlin, Germany.

Supported by a grant from the German Research Council (DFG, Bu 623/2-3). $\mathrm{pmol} / \mathrm{mL}, p<0.05)$ also when considering GA and ANC as covariates. In contrast, increased SCD62L levels in infants born from meconium-stained amniotic fluid, and decreased levels in newborns with acute bacterial infection could be fully attributed to differences in GA and ANC. Umbilical cord blood SCD62L levels of healthy, term, vaginally born singletons $(n=38)$ were significantly lower $(8.5 \pm 2.2$ versus $11.8 \pm 1.9, p<0.0001)$ than cubital vein levels of healthy adults $(n=20)$. We conclude that $\mathrm{SCD} 62 \mathrm{~L}$ levels display a strong increase during fetal maturation. (Pediatr Res 38: 336-341, 1995)

CD62L, L-selectin

\section{Abbreviations}

sCD62L, soluble L-selectin

CRP, C-reactive protein

TBS, Tris-buffered saline

PMSF, phenylmethylsulfonyl fluoride

GA, gestational age

ANC, absolute neutrophil count

in vivo $(17,18)$. Human serum has been shown to contain SCD62L with its functional activity retained (19). There is little information available on the diagnostic and physiologic significance of serum sCD62L levels. In adults, high levels have been reported in patients with acute leukemia (20), whereas modest elevations were found in patients with sepsis, AIDS (21), and recent-onset insulin-dependent diabetes mellitus (22). In contrast, patients with multiple trauma, perforated bowel, or acute pancreatitis presented with plasma sCD62L levels on admission that were lower than those of healthy controls (23).

We have shown previously that surface-expressed CD62L is decreased in newborns with acute bacterial infection irrespective of GA $(17,18)$. Hypothesizing that SCD62L levels might be conversely increased in conditions associated with generalized activation of the immune system, we developed an ELISA to quantitate SCD62L in umbilical cord vein plasma of human term and preterm newborns. The ELISA and the data obtained of cord blood SCD62L levels with respect to maturity, hematologic, and obstetrical conditions are the subject of the following report. 


\section{METHODS}

\section{Subjects}

SCD62L levels were determined in umbilical cord vein blood of 255 neonates with a GA of 23-43 wk (median 38 wk), and a birth weight ranging from 420 to $5100 \mathrm{~g}$ (median 3080 g). Antepartum and intrapartum data were collected prospectively and included gender ( 145 boys), multiple gestation $(n=$ $40)$, gestational hypertension $(n=13)$, gestational diabetes $(n$ $=21$ ), meconium-stained amniotic fluid $(n=69)$, umbilical artery $\mathrm{pH}$, and mode of delivery. Asphyxia (umbilical artery $\mathrm{pH}<7.15$ ) occurred in 15 newborns. One-hundred and fifty newborns were born vaginally (53 assisted by vacuum or forceps), 75 by elective, and 30 by emergency cesarean delivery. Healthy, mature ( $\mathrm{GA} \geq 37 \mathrm{wk}$ ), vaginally born singletons without any of the risk factors gestational hypertension, gestational diabetes, meconium-stained amniotic fluid or asphyxia comprised 38 of the 255 newborns. Although all infants were born at the same tertiary perinatal center, the distribution of risk factors is not necessarily representative for that of the institution.

Laboratory work-up was initiated at the discretion of the attending neonatologist in 189 of the 255 newborns. No venipunctures of the infant were made for investigational purposes. In 153 newborns, a white blood cell count and differential was obtained within the first $6 \mathrm{~h}$ of life (24). As further markers of inflammation, CRP serum peak values obtained within the first $36 \mathrm{~h}$ of life (25), and platelet count nadir values within the first $72 \mathrm{~h}$ of life were recorded (26). A decision of transferal to the children's hospital within the first $24 \mathrm{~h}$ of life was made in 112 newborns. For the purpose of this study, a diagnosis of acute bacterial infection was made $(n=15)$ if clinical symptoms leading to the institution of antibiotics within the first $24 \mathrm{~h}$ of life were confirmed by a positive venous blood culture and at least one of the four laboratory parameters outlined below, or at least two parameters in culture-negative newborns placed on i.v. antibiotics after antibiotics had been administered i.v. to the mother before delivery for suspected amnion infection syndrome. Laboratory markers of presumed acute bacterial infection were neutropenia ( $\mathrm{ANC} \leq 2000 / \mu \mathrm{L} ; n=13$ ), a pathologic neutrophil immature/total ratio $(\geq 0.2 ; n=16)$, peak CRP serum levels of $10 \mathrm{mg} / \mathrm{L}$ or more $(n=27)$, and thrombocytopenia (nadir $<150000 / \mu \mathrm{L} ; n=17$ ).

Umbilical cord vein blood was prevented from clotting by addition of sodium citrate immediately after birth and centrifuged within $6 \mathrm{~h}$ after delivery. The plasma was stored at $-20^{\circ} \mathrm{C}$ until analysis. After thawing, plasma samples were diluted $1 / 25$ to obtain a measure in the linear range of the assay developed. Raw data obtained from plasma were corrected for hematocrit and the volume of sodium citrate added.

For comparison, SCD62L levels were quantitated in cubital vein plasma $(n=20)$ of adults without apparent inflammatory disease. In matched samples of 96 or 127 newborns, respectively, umbilical cord blood SCD62L levels were compared with lymphocyte, or granulocyte and monocyte CD62L surface expression measured by flow cytometry described previously $(17,18)$.

\section{Determination of $\mathrm{sCD6} 2 \mathrm{~L}$ Levels}

$M A b$. The anti-CD62L MAb DREG-55 and DREG-200 hybridomas (27) were grown in serum-free medium (Ultroser, GIBCO, Eggenstein, Germany). Supernatants were purified by protein $\mathrm{G}$ affinity chromatography using the MAbTrapG-Kit (Pharmacia, Freiburg, Germany). Purity was checked by SDSPAGE under reducing and nonreducing conditions (PhastSystem, Pharmacia). Purified DREG-200 was biotinylated in 0.1 $\mathrm{M}$ borate buffer $(\mathrm{pH} 8.8)$ with a freshly prepared $1 \%(\mathrm{wt} / \mathrm{vol})$ solution of biotinamidocaproate- $N$-hydroxysuccinimide ester (Sigma Chemical Co., Deisenhofen, Germany) in DMSO for $20 \mathrm{~h}$ at room temperature, at a molecular ratio of biotin ester:IgG $=30: 1$, followed by blocking of unreacted succinimide ester groups by addition of $1 \mathrm{M} \mathrm{NH}_{4} \mathrm{Cl}$.

Preparation of an $S C D 62 L$-enriched standard. A DREG 55-Sepharose 4B column (2.8 mg DREG 55 per $\mathrm{mL}$ gel) was prepared according to the manufacturer's instructions from BrCN-activated Sepharose 4B (Pharmacia) and equilibrated with PBS containing $0.05 \% \mathrm{NaN}_{3}, 2 \mathrm{mM}$ EDTA, and $0.2 \mathrm{mM}$ PMSF. Pooled plasma of healthy adult blood donors was cleared by centrifugation $\left(2 \mathrm{~h}\right.$ at $0^{\circ} \mathrm{C}$ and $\left.2500 \times g\right)$, filtered through $0.2 \mu \mathrm{m}$ filters (Schleicher \& Schüll, Dassel, Germany), and diluted $1: 1$ with PBS $\left(0.05 \% \mathrm{NaN}_{3}, 2\right.$ mM EDTA, $0.2 \mathrm{mM}$ PMSF). After passage over the DREG-55 affinity column and elution with $0.1 \mathrm{M}$ glycine buffer $(\mathrm{pH} 2.7)$, fractions were immediately neutralized with $1 \mathrm{M}$ Tris buffer ( $\mathrm{pH}$ 9.0). Peak protein fractions were concentrated and transferred into PBS $\left(0.05 \% \mathrm{NaN}_{3}, 2 \mathrm{mM}\right.$ EDTA, $0.2 \mathrm{mM}$ PMSF) by ultrafiltration (Centricon 10 unit; Amicon, Beverly, MA) yielding 5-11 $\mu \mathrm{g}$ protein/mL plasma (Micro-BCA-method with BSA as the standard; Pierce, Oud-Beijerland, The Netherlands).

The SCD62L preparation was characterized by $12.5 \%$ SDSPAGE followed by blotting on Hybond ECL cellulose membranes (0.45 um, Amersham Buchler, Braunschweig, Germany) using the PhastSystem including the Semi-dry Transfer Kit (Pharmacia). Protein bands were visualized by silver staining, parallel blots were immunostained with biotinylated MAb DREG-55 (dilution 1:500) followed by ExtrAvidin alkaline phosphatase conjugate (dilution 1:3000) and development with NBT/BCIP reagent ( $p$-nitro blue tetrazolium chloride/5bromo-4-chloro 3-indolyl phosphate toluidine salt; Bio-Rad, Munich, Germany) following the manufacturer's instructions.

Standardization of the plasma $S C D 62 L$ preparation by competition titration. Polystyrene Falcon tubes (5-mL; Becton Dickinson, Heidelberg, Germany) were blocked with $1 \%$ BSA in TBS with $0.02 \% \mathrm{NaN}_{3}$ for $3 \mathrm{~h}$ at room temperature and washed three times, with careful aspiration after the last washing step but without drying the tubes. Then $100 \mathrm{ng}$ of MAb DREG 55, or DREG 200, and $100 \mu \mathrm{L}$ of the standard plasma SCD62L preparation containing $150,100,50,12.5,6.25,1.25$, $0.625,0.125,0.0125,0.00125$, and $0 \mu \mathrm{g}$ (negative control) of protein were pipetted into the tubes, vortexed, and preincubated for $1 \mathrm{~h}$ at room temperature in the presence of $0.05 \%$ $\mathrm{NaN}_{3}, 2 \mathrm{mM}$ EDTA, and $0.2 \mathrm{mM}$ PMSF. A leukocyte suspension was prepared by washing a fresh buffy coat three times at $600 \times g$ and twice at $180 \times g$ for $10 \mathrm{~min}$ in excess RPMI 1640 , 
with a final resuspension in PBS containing $0.2 \% \mathrm{NaN}_{3}$, $0.15 \% \mathrm{BSA}$, and $0.1 \%$ human $\mathrm{IgG}$. To each coated tube, 3 $\times 10^{5}$ leukocytes in $50 \mu \mathrm{L}$ were added, vortexed, and allowed to react for $10 \mathrm{~min}$ at room temperature and $30 \mathrm{~min}$ at $4^{\circ} \mathrm{C}$. The cells were washed three times with the $\operatorname{lgG}$ containing buffer and incubated with $7 \mu \mathrm{L}$ of goat-antimouse-IgG(H+L)F $\left(a b^{\prime}\right)_{2}-\mathrm{FTC}$ for $30 \mathrm{~min}$ at $0^{\circ} \mathrm{C}$ (Dianova, Hamburg, Germany). After addition of $4 \mathrm{~mL}$ of FACS, lysing solution (Becton Dickinson), vortexing, and 10-min incubation at $0^{\circ} \mathrm{C}$, the samples were centrifuged, the supernatants were aspirated, and the samples were washed again with PBS. Finally, the samples were postfixed by addition of $350 \mu \mathrm{L}$ of $2 \%$ paraformaldehyde in $1.5 \times \operatorname{PBS}\left(1 \mathrm{~h}\right.$ at $\left.5^{\circ} \mathrm{C}\right)$. Using a FACScan flow cytometer (Becton Dickinson), median fluorescence intensities $\left(10^{4}\right.$ cells/point) were measured and plotted against the logarithm of the protein amount of the standard plasma $S C D 62 \mathrm{~L}$ preparation. The content of immunologically active SCD62L of the standard SCD62L preparation was calculated from the protein amount at the inflection point of the sigmoid neutralization curves, assuming a molecular mass of $150 \mathrm{kD}$ for $\mathrm{IgG}$ and a binding ratio of $2 \mathrm{CD} 62 \mathrm{~L}$ molecules per anti-CD62L MAb.

ELISA. The wells of black microwell plates (F16 black maxisorp immuno modules; Nunc, Roskilde, Denmark) were coated each with $100 \mu \mathrm{L}$ of DREG $55(10 \mu \mathrm{g} / \mathrm{mL})$ in $50 \mathrm{mM}$ carbonate buffer ( $\mathrm{pH} 9.85$ ) at $4^{\circ} \mathrm{C}$ for $18 \mathrm{~h}$. After three washes, the wells were blocked with $1 \%$ BSA in TBS for $2 \mathrm{~h}$ at $37^{\circ} \mathrm{C}$. Quadruplicate serial dilutions of the CD62L standard (0.075$0.746 \mathrm{pmol} / \mathrm{mL})$ and $1: 25$ dilutions of plasma samples were incubated for $1 \mathrm{~h}$ at $37^{\circ} \mathrm{C}$. After washing with TBS containing $0.05 \%$ Tween 20 , the wells were incubated with $100 \mu \mathrm{L}$ of DREG 200-biotin conjugate for $1 \mathrm{~h}$ at $37^{\circ} \mathrm{C}$, washed again, and incubated for $1 \mathrm{~h}$ at $37^{\circ} \mathrm{C}$ with $100 \mu \mathrm{L} /$ well of a $1: 3000$ dilution of ExtrAvidin alkaline phosphatase conjugate (Sigma Chemical Co.). After three further washing steps, the wells were finally incubated with $100 \mu \mathrm{L}$ of a 1:50 dilution of the luminescent substrate Lumigen PPD (Boehringer Mannheim, Mannheim, Germany) in $0.1 \mathrm{M}$ Tris buffer ( $\mathrm{pH}$ 9.5, $0.1 \mathrm{M}$ $\mathrm{NaCl}, 50 \mathrm{mM} \mathrm{MgCl}_{2}$ ) at room temperature. The luminescence (relative light units) was read with an ML 1000 luminometer (Dynatech, Denkendorf, Germany) in the plateau phase after $30 \mathrm{~min}$ at $24-28^{\circ} \mathrm{C}$.

Statistical analysis. Spearman correlation coefficients were calculated to measure the strength of association between numerical variables. Differences between groups defined by categorical variables were assessed by the $\chi^{2}$ test, MannWhitney $U$ test, or Kruskal-Wallis test for more than one group. Analysis of variance was used for multiple regression analysis of several numerical variables and to assess the influence on numerical variables of categorical variables in the presence of numerical covariates. The Kolmogorov-Smirnov goodness of fit test was used to assess normal (Gaussian) distribution. Means \pm SD are given when the distribution of values did not differ significantly from a normal distribution. All statistical tests were based on a significance level of 0.05 with two-sided $p$ values.

\section{RESULTS}

The ELISA developed to quantitate SCD62L in human plasma has a sensitivity (negative control $+3 \mathrm{SD}$ ) of 17 $\mathrm{fmol} / \mathrm{mL}$. The intraassay coefficient of variation is $<5 \%$, the interassay coefficient of variation is $<8 \%$, and the optimal working range is $0.06-0.6 \mathrm{pmol} / \mathrm{mL}$. In adult cubital vein plasma, sCD62L levels were $12.4 \pm 2.1 \mathrm{pmol} / \mathrm{mL}$ (mean \pm $\mathrm{SD}, n=20$ ).

In cord blood samples of 255 newborns, sCD62L levels were $7.2 \pm 2.5 \mathrm{pmol} / \mathrm{mL}$. Compared with peripheral vein plasma of adults, cord blood plasma of term and postterm newborns (GA $\geq 37 \mathrm{wk}, n=170$ ) had significantly ( $p<$ $0.0001)$ lower sCD62L levels $(8.4 \pm 1.9 \mathrm{pmol} / \mathrm{mL})$. Samples of premature newborns (GA 31-36 wk, $n=59$ ) and extremely premature newborns (GA 23-30 wk, $n=26$ ) had considerably less $\mathrm{sCD} 62 \mathrm{~L}(5.4 \pm 1.5 \mathrm{pmol} / \mathrm{mL}$, or $3.7+2.4 \mathrm{pmol} / \mathrm{mL}$, respectively). Differences between all groups were significant $(p<0.001)$. sCD62L levels of healthy, mature (GA $\geq 37 \mathrm{wk})$, vaginally born singletons without any of the risk factors gestational hypertension, gestational diabetes, meconium-stained amniotic fluid or asphyxia $(n=38)$ were similar $(8.5 \pm 2.2$ $\mathrm{pmol} / \mathrm{mL}$ ) to those of the other term newborns but differed from adult cubital vein levels $(p<0.0001)$. In all groups described, the distribution of SCD62L levels did not differ significantly from that expected for a normal distribution $(p>$ $0.1)$

Linear regression analysis confirmed a strong correlation between cord blood SCD62L level and GA $(r=0.71, p<$ $0.001)$, as well as birth weight $(r=0.66, p<0.001$, Fig. 1$)$. A positive correlation of cord blood sCD62L levels was also found with ANC $(r=0.62, p<0.001)$ obtained from a peripheral vein within the first $6 \mathrm{~h}$ of life in 153 newborns, whereas there was a weak inverse correlation of SCD62L levels with absolute normoblast counts $(r=-0.27, p<0.001)$. Cord blood SCD62L levels, GA, birth weight, ANC, and absolute normoblast counts were found to be highly interrelated (Table 1). By multiple regression analysis, GA and ANC both appeared to be independently associated with SCD62L levels $(p$ $<0.001)$ but not birth weight and absolute normoblast counts $(p>0.1)$.

No correlation $(-0.25<r<0.25)$ was seen between sCD62L levels and umbilical artery $\mathrm{pH}$, hematocrit, absolute lymphocyte/monocyte counts, neutrophil immature/total ratio, platelet count nadir within the first $72 \mathrm{~h}$ of life, CRP serum level peak during first $36 \mathrm{~h}$ of life, or umbilical cord blood CD62L surface expression $(17,18)$ of lymphocytes $(n=96)$, granulocytes $(n=127)$, or monocytes $(n=127)$, either by single comparison or by multiple regression analysis considering GA and ANC as covariates.

There was no apparent relationship $(p>0.05)$ between cord blood $\mathrm{SCD} 62 \mathrm{~L}$ levels and the categorical variables gender, gestational hypertension, gestational diabetes, or asphyxia (umbilical artery $\mathrm{pH}<7.15$ ) either by direct comparison or when GA and ANC were considered as covariates. Infants born from meconium-stained amniotic fluid appeared to have increased sCD62L levels $(p<0.01)$. This complication was mostly seen in term and postterm infants $(p<0.0001)$. When 

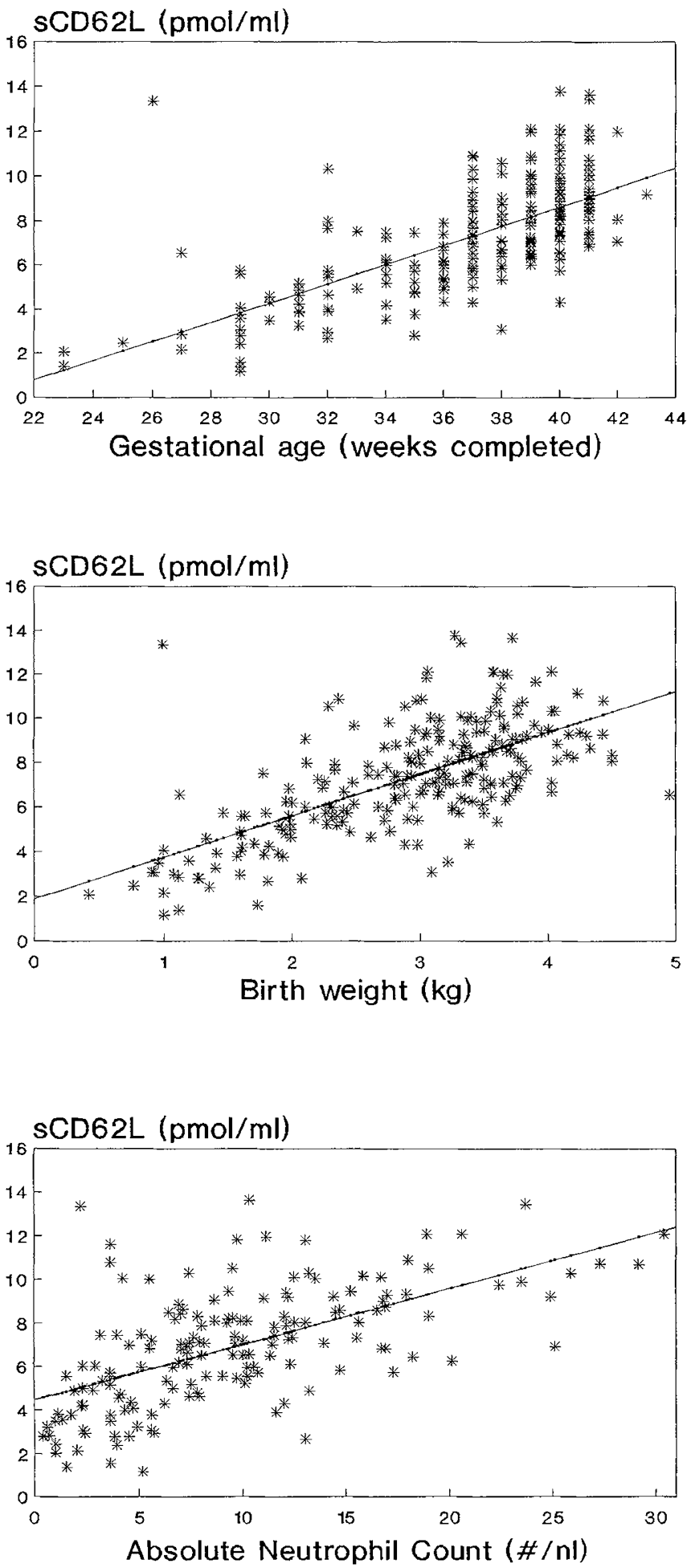

Figure 1. Scatter plots with regression lines showing association of umbilical cord plasma SCD62L levels and GA (top), birth weight (middle), and ANC (bottom).

GA and ANC were considered as covariates, the difference was no longer significant $(p>0.1)$.

The most striking feature of newborns with acute bacterial infection was their higher immature/total ratio of the first differential (median 0.26 versus 0.03 ) compared with controls $(p<0.0001)$. In addition, newborns with acute bacterial
Table 1. Spearman correlation coefficients of $S C D 62 L$ levels, GA, birth weight, ANC, and normoblast counts

\begin{tabular}{lccccc}
\hline \multicolumn{1}{c}{ Variable } & $\begin{array}{c}\text { sCD62L } \\
\text { level }\end{array}$ & GA & Birth weight & ANC & $\begin{array}{c}\text { Normoblast } \\
\text { count }\end{array}$ \\
\hline sCD62L level & 1 & 0.71 & 0.66 & 0.62 & -0.27 \\
GA & & 1 & 0.78 & 0.66 & -0.27 \\
Birth weight & & & 1 & 0.65 & -0.36 \\
ANC & & & & 1 & -0.29 \\
\hline
\end{tabular}

For all coefficients, 2-sided $p<0.001$.

infection had significantly $(p<0.05)$ lower ANC (median $4500 / \mu \mathrm{L}$ versus $9200 / \mu \mathrm{L}$ ), a lower birth weight (median 1945 $\mathrm{g}$ versus $3120 \mathrm{~g}$ ), a lower GA (median 34 versus $38 \mathrm{wk}$ ), lower platelet count nadirs (median $196000 / \mu \mathrm{L}$ versus $260000 / \mu \mathrm{L}$ ), higher CRP peak levels (median $21 \mathrm{mg} / \mathrm{L}$ versus $3 \mathrm{mg} / \mathrm{L}$ ), and lower sCD62L levels (median 5.56 versus $7.35 \mathrm{pmol} / \mathrm{mL}$ ). The lower SCD62L levels in newborns with acute bacterial infection were found to be insignificant $(p>0.1)$ when GA and ANC were considered as covariates. There was no significant association $(p>0.1)$ of cord plasma SCD62L levels and a pathologic immature/total ratio $(\geq 0.2)$, with or without correction for GA and ANC. Newborns with platelet counts nadirs below $150000 / \mu \mathrm{L}$ had slightly lower $\mathrm{SCD} 62 \mathrm{~L}$ levels but the significance of this association was lost after correction for GA and ANC $(p>0.1)$. Cord blood SCD62L levels were higher in newborns who had peak CRP serum levels of $10 \mathrm{mg} / \mathrm{L}$ or more during the first $36 \mathrm{~h}$ of life than in newborns whose CRP levels were consistently below $10 \mathrm{mg} / \mathrm{L}(8.3 \pm 2.3 \mathrm{pmol} / \mathrm{mL}$ versus $7.1 \pm 2.5 \mathrm{pmol} / \mathrm{mL}, p<0.05$ without, $p<0.01$ with correction for GA and ANC).

Samples from twins and triplets had lower cord blood sCD62L levels than singletons $(4.8 \pm 2.4 \mathrm{pmol} / \mathrm{mL}$ versus 7.7 $\pm 2.3 \mathrm{pmol} / \mathrm{mL}, p<0.0001$ by uncorrected comparison, $p<$ 0.01 when taking GA and ANC into account). Cord blood SCD62L levels were lower in samples of neonates born by elective cesarean section $(5.6 \pm 2.6 \mathrm{pmol} / \mathrm{mL})$ than by any other mode of delivery $(7.9 \pm 2.1 \mathrm{pmol} / \mathrm{mL}, p<0.01)$. However, 29 of 40 twins and triplets were born by elective cesarean delivery, compared with 46 of 215 singletons $(p<$ 0.0001 ), and GA and ANC were lower in infants born by elective cesarean delivery $(p<0.0001)$ compared with other modes of delivery. When considering GA, ANC and multiple gestation as confounding variables, no impact of the mode of delivery on SCD62L levels could be demonstrated $(p>0.1)$.

\section{DISCUSSION}

In the absence of purified recombinant $\mathrm{SCD} 62 \mathrm{~L}$, efforts to quantitate SCD62L in human plasma or serum have yielded slightly conflicting results. Using three different methods (densitometry of SDS-PAGE bands of partially purified SCD62L, or purified recombinant CD62L-IgG chimeras, or Scatchard plot quantitation of surface CD62L expressed in CD62L cDNA transfectants followed by phorbol 12-myristate 13-acetateinduced shedding) (21), the SCD62L content of a standard plasma has been estimated between 0.95 and $3 \mu \mathrm{g} / \mathrm{mL}(11.9-$ $37.5 \mathrm{pmol} / \mathrm{mL}$ ). Our competition titration experiments favor the lower end of that range. Others have abandoned absolute 
quantitation, giving only relative values instead $(25,28)$. Efforts are under way to express human cDNA-derived CD62L in a prokaryotic system to allow a more precise quantitation of human SCD62L. However, this will not change the validity of conclusions reached by comparing values obtained by the same assay.

The increase of SCD62L plasma levels during the course of fetal maturation could be related to several factors. Nucleated lymphohematopoietic cells are the only known source of sCD62L. Circulating neutrophil numbers and sCD62L levels were indeed found to be closely related in human newborns. A close correlation of serum $\mathrm{SCD} 62 \mathrm{~L}$ levels to peripheral leukocyte counts has been found in a study of patients with chronic leukemia undergoing bone marrow transplantation, with no detectable sCD62L during periods of severe leukopenia (28). Peripheral white blood cell counts are only a rough estimate of the total number of leukocytes in the body, most of which express CD62L. To a variable extent, CD62L is also found on progenitor cells in the spleen, thymus, and bone marrow which are not amenable to quantitative anaylsis under normal circumstances $(10,11)$.

sCD62L levels can be expected to be heavily influenced by basal leukocyte CD62L expression and CD62L shedding rates. CD62L expression of neutrophils of term newborns is lower than that of adults $(18,29-31)$. However, neutrophils in cord blood of immature newborns and in fetal samples obtained percutaneously express CD62L at adult levels $(18,32)$. CD62L expression of monocytes and lymphocytes is not different between adults and newborns and does not decrease with GA $(28,30)$. In addition, there is no apparent relationship between sCD62L levels and surface CD62L expression of any major circulating leukocyte population. CD62L shedding in response to stimulation in vitro has been shown to occur at similar rates in monocytes of adults and term newborns (30). In neutrophils, stimulation-induced CD62 L down-regulation is lower in term newborns than in adults (29-31). However, fetal neutrophils shed CD62 $\mathrm{L}$ at adult rates in response to stimulation (31). The low levels of $\mathrm{sCD} 62 \mathrm{~L}$ in premature human newborns thus do not reflect decreased basal leukocyte surface expression nor an impaired shedding response to stimulation.

CD62L shedding appears to occur also without activation at low levels, generating steady state plasma levels already under normal conditions. Nothing is known about baseline CD62L turnover, the mechanism of clearance and the half-life of circulating SCD62L. Measuring circulating SCD62L is likely to miss shed SCD62L bound to CD62L ligand-bearing cells. Enhanced expression of such ligands can be assumed to result in decreased levels of circulating SCD62L but the distribution of such ligands in fetal tissue including the placenta is unknown.

Proteolytic cleavage of $\mathrm{CD} 62 \mathrm{~L}$ from the cell surface is rapidly accelerated after activation in vitro (12-16) and in vivo $(17,18)$. In human newborns, acute bacterial infection is reflected in a reduced $\mathrm{CD} 62 \mathrm{~L}$ surface membrane expression of lymphocytes, granulocytes, and monocytes, but not in increased sCD62L levels. Neutropenia is common in neonatal early onset sepsis, and increased shedding rates are likely to be counteracted by decreased numbers of cells serving as a source of SCD62L. In addition, activation-induced endothelial expression of $\mathrm{CD} 62 \mathrm{~L}$ ligands may lead to enhanced sequestration of sCD62L, contributing to a further decline of sCD62L levels.

Depending on the actual plasma level, sCD62L may interfere with leukocyte extravasation. Anti-CD62L MAbs or CD62L-Ig chimeric molecules have be used successfully to protect rats against neutrophil-mediated lung injury $(33,34)$. In adult patients at risk for the development of acute respiratory distress syndrome, a significant correlation has been found between low initial SCD62L levels and indices of subsequent lung injury, such as requirement for ventilation and degree of respiratory failure, as well as patient mortality (23). It is tempting to speculate that the high susceptibility of premature newborns to disseminated inflammatory lung disease may be related in part to their low levels of circulating sCD62L.

Acknowledgments. We would like to thank Evy Waiß for expert technical assistance, Boris Metze and Reinhard Hartmann for help with data management and statistical advice, and Günter Henze for access to flow cytometry equipment.

\section{REFERENCES}

1. Lewinsohn D, Bargatze R, Butcher EC 1987 Leukocyte-endothelial cell rccognition: Evidence of a common molecular mechanism shared by neutrophils, lymphocytes, and other leukocytes. J Immunol 138:4313-4321

2. Ley K, Gaethgens P, Fennic C, Singer MS, Lasky LA, Rosen SD 1991 Lectin-like cell adhesion molecule 1 mediates leukocytc rolling in mesenteric venules in vivo. Blood $77: 2553-2555$

3. von Andrian UH, Chambers JD. McEvoy LM, Bargatze REF, Arfors K-E, Butcher EC 1991 Two-step model of leukocyte-endothelial cell intcraction in inflammation: Distinct roles for LECAM-1 and the leukocyte $\beta 2$ integrins in vivo. Proc Natl Acad Sci USA 88:7538-7542

4. Watson SR, Fennic C, Lasky LA 1991 Neutrophil influx into an inflammatory site inhibited by a solublc homing receptor-IgG chimera. Naturc 349:164-167

5. Picker LJ, Butcher EC 1992 Physiologic and molecular mechanisms of lymphocyte homing. Annu Rev Immunol 10:561-591

6. Dawson J, Sedgwick AD, Edwards JCW, Lees P 1992 The MAb MEL-14 can block lymphocyte migration into a site of chronic inflammation. Eur J Immunol 22:16471650

7. Simon SI, Rochon YP, Lynam EB, Smith CW, Anderson DC, Sklar LA 1993 $\beta 2$-Integrin and $\mathrm{t}$-selectin are obligatory receptors in neutrophil aggregation. Blood 82:1097-1106

8. Strauch UG, Holzmann B 1993 Triggering of 1 -selectin (gp90 9 ME:-14 $)$ induces homotypic lymphocyte adhesion by a mechanism independent of LFA-1. Int Immunol $5: 393-398$

9. Buttrum SM, Hatton R, Nash GB 1993 Selectin-mediatcd rolling of neutrophils on immobilized platelets. Blood 82:1165-1174

16. Kansas GS, Muirhead MJ, Dailcy MO 1990 Expression of the CD11/CD18, leukocyte adhesion molecule 1, and CD44 adhesion molecules during normal myeloid and erythroid differentiation in humans. Blond 76:2483-2492

11. Terstappen LWMM, Huang S, Picker LJ 1992 Flow cytometric assessment of human T-cell differentiation in thymus and bone marrow. Blood 79:666-677

12. Kishimoto TK, Jutila MA, Berg EL, Butcher EC 1989 Neutrophil Mac-1 and MEL-14 adhesion protcins inversely regulated by chemotactic factors. Science 245:1238-1241

13. Berg M, James SP 1990 Human neutrophils release the Leu-8 lymph node honing receptor during cell activation. Blood 76:2381-2388

14. Griffin JD, Spertini O, Ernst TJ, Belvin MP, Levine HB, Kanakura X, Tedder TF 1990 Granulocyte-macrophage colony-stimulating factor and other cytokines regulate surface expression of the lcukocytc adhesion molcculc-1 on human ncutrophils, monocytes, and their prccursors. J Immunol 145:576-584

15. Bührer C, Berlin C, Thiele H-G, Hamann A 1990 Lymphocyte activation and expression of the human lcukocyte-endothelial cell adhesion molecule 1 (Lcu8/TQ1antigen). Immunology 71:442-448

16. Jung TM, Dailey MO 1990 Rapid modulation of homing receptors (gp90 MEL-14) induced by activators of protcin kinase $C$. Receptor shedding due to accelerated proteolytic cleavage at the cell surface. J Immunol 144:3130-3136

17. Bührer C, Luxenburger U, Metze B, Kattner E, Henzc G, Dudenhausen JW, Obladen M 1993 Diminished cord blood lymphocyte $\mathrm{L}$-selectin expression in neonatal bacterial infection. Eur J Pediatr 152:519-522

18. Bührer C, Graulich J, Stibenz, D, Dudenhausen JW, Obladen M 1994 1.-Selectin is down-regulated in umbilical cord blood granulocytes and monocytes of newborn infants with acute bacterial infection. Pcdiatr Res 36:799-804

19. Schiciffenbaum B, Spertini O, Tedder TF 1992 Soluble L-selcctin is present in human plasma at high levels and retains functional activity. J Cell Biol 119:229-238 
20. Spertini O, Callegari P, Cordey A-S, Hauert J, Joggi J, von Fliedner V, Shapira M 1994 High levels of the shed form of $\ell$-selectin are present in patients with acute leukemia and inhibit blast cell adhesion to activated endotheitum. Blood 84:1249-1256

21. Spertini O, Schleiffenbaum B, White-Owen C, Ruiz Jr P, Tedder TF 1992 ELISA fo quantitation of L-selectin shed from leukocytes in vivo. J Immunol Methods 156 $115-123$

22. Lampeter ER, Kishimoto TK, Rothlein R, Mainolfi EA, Bertrams J, Kolb H, Martin S 1992 Elevated levels of circulating adhesion molecules in IDDM patients and in subjects at risk for IDDM. Diabetes 41:1668-1671

23. Donnelly SC, Haslett C, Dransfield I, Robertson CE, Carter DC, Ross JA, Grant IS Tedder TF 1994 Role of selectins in development of adult respiratory distress syndrome. Lancet 344:215-219

24. Manroe BL, Weinberg AG, Rosenfeld CR, Browne R 1979 The neonatal blood coun in health and disease. I. Reference values for neutrophilic cells. J Pediatr 95:89-98

25. Mathers NJ, Pohlandt F 1987 Diagnostic audit of C-reactive protein in neonatal infection. Eur J Pediatr 146:147-151

26. Corrigan JJ 1974 Thrombocytopenia: A laboratory sign of septicemia in infants and children. J Pediatr 85:219-221

27. Kishimoto TK, Jutila MA, Butcher EC 1990 Identification of human peripheral lymph node homing receptor: a rapidly down-regulated adhesion molecule. Proc Natl Acad Sci USA 87:2244-2248
28. Zetterberg E, Richter J 1993 Correlation between serum level of soluble $\mathrm{L}_{\text {-selectin }}$ and leukocyte count in chronic myeloid and lymphocytic leukemia and during bone marrow transplantation. Eur J Haematol 51:113-119

29. Anderson DC, Abbassi O, Kishimoto TK, Koenig JM, McIntire LV, Smith CW 1991 Diminished lectin-, epidermal growth factor-, complement binding domain-cell adhesion molecule- 1 on neonatal neutrophils underlies their impaired CD18independent adhesion to endothelial cells in vitro. J Immunol 146:3372-3379

30. Török C, Lundahi J, Hed J, Lagercrantz H 1993 Diversity in regulation of adhesion molecules (Mac-1 and L-selectin) in monocytes and neutrophils from neonates and adults. Arch Dis Child 68:561-565

31. Smith JB, Kunjummen RD, Kishimoto TK, Anderson DC 1992 Expression and regulation of L-selectin on eosinophils from human adults and neonates. Pediatr Res $32: 465-471$

32. Smith JB, Tabsh KMA 1993 Fetal ncutrophils and eosinophils express normal levels of L-selectin. Pediatr Res 34:253-257

33. Mulligan MS, Watson SR, Fennie C, Ward PA 1993 Protective effects of selectin chimeras in neutrophil-mediated lung injury. J Immunol 151:6410-6417

34. Mulligan MS, Miyasaka M, Tamatani T, Jones ML, Ward PA 1994 Requirements for $\mathrm{L}$-selectin in neutrophil-mediated lung injury in rats. J Immunol 152:832-840 